\author{
IWONA KAPROŃ-CHARZYŃSKA \\ (D) https://orcid.org/0000-0001-5798-2592 \\ Uniwersytet Mikołaja Kopernika w Toruniu \\ Toruń
}

\title{
Nauczanie fonetyki języka polskiego z perspektywy logopedycznej - studium przypadku studentów z Chin
}

Teaching Polish phonetics from the point of view of speech therapy - case study involving Chinese students

\begin{abstract}
The paper discusses the inclusion of speech therapy stages and methods used in speech therapy in the process of teaching phonetics of Polish as a foreign language. The case study shows that their application made it easier to determine the nature of the deviations from the standard occurring among the students and to design a comprehensive set of targeted measures to improve phonetic and phonological competences. The proposed solutions refer to a group of people whose first language was Chinese, but they can be applied in the teaching of phonetics of different foreign languages.
\end{abstract}

Keywords: Polish as a foreign language, phonetic and phonological competences, speech therapy

\section{Wstęp}

W artykule podjęto zagadnienie włączania do glottodydaktyki osiagnięć logopedii w nauczaniu fonetyki języka obcego. W ramach prowadzonych zajęć językowych zaproponowano uwzględnianie etapów postępowania oraz metod i technik wykorzystywanych w logopedii. Przedstawione rozważania odnoszą się do studentów z pierwszym językiem chińskim uczących się języka polskiego' ${ }^{1}$ W części analitycznej tekstu skoncentrowano się na realizacji spółgłosek i półsamogłoski [u]].

1 Z grupa dziesięciorga studentów chińskich, będących podmiotem badań, autorka artykułu prowadziła zajęcia z fonetyki w wymiarze 15 godzin w roku akademickim 2018/2019 na Uniwersytecie Mikołaja Kopernika w Toruniu. 


\section{Łączenie perspektyw glottodydaktycznej i logopedycznej w świetle literatury przedmiotu}

W literaturze przedmiotu z jednej strony podkreśla się, że nauczanie wymowy języka polskiego jest ważne z punktu widzenia rozwijania kompetencji komunikacyjnej obcokrajowców (Seretny, Lipińska 2005), z drugiej zaś, że jest to zaniedbana czynność dydaktyczna (por. Seretny, Lipińska 2005; Tambor 2010; 2012; Kubicka 2010). Zwraca się uwagę na czynniki determinujące naukę (por. Tambor 2010; 2012), dobór metod i proponowanych technik w podręcznikach do nauki języka polskiego jako obcego (Biernacka 2015). Analizuje się trudności poszczególnych grup cudzoziemców w opanowywaniu wymowy (Wójtowicz 1980; Tambor 2010; Majewska-Tworek 2005; Szmidt, Castellví 2011; Młynarczyk 2013).

W ostatnich latach przedmiotem zainteresowania badaczy jest także nauczanie wymowy polskiej obcokrajowców z perspektywy logopedii. Połączenie dwóch podejść - glottodydaktycznego i logopedycznego - przyniosło ciekawe obserwacje, które odnoszą się do problematyki:

1) dwu- lub wielojęzyczności i wsparcia dzieci z rodzin bi- i wielolingwalnych (por. np. Madelska 2010; Cieszyńska-Rożek 2015; 2018; Młyński 2012; Węsierska 2014; Bielawska 2018; Kyrc 2018). W tym zakresie wskazuje się na wzajemne oddziaływania glottodydaktyki i logopedii oraz na narzędzia, które można wykorzystać w budowaniu systemu językowego;

2) nauczania języka polskiego młodzieży i dorosłych, posługujących się różnymi od polskiego językami pierwszymi. W tym nurcie, w którym mieszczą się także rozważania zawarte $\mathrm{w}$ artykule, podjęto kilka zagadnien. Zwrócono uwage na przyczyny trudności w zakresie wymowy u cudzoziemców uczących się polskiego. Wśród nich, obok czynników dotyczących języka wcześniej przyswojonego czy sposobu uczenia wymowy w przypadku poznawania języka drugiego, wskazano także te o charakterze biologicznym oraz podkreślono wpływ języka pierwszego w powiązaniu z warunkami anatomiczno-czynnościowymi na nauczanie języka drugiego (por. Pluta-Wojciechowska 2015). Wskazano, że na zajęciach języka polskiego jako obcego moga się pojawić kursanci, u których występuja zakłócenia w nabywaniu kompetencji językowej i komunikacyjnej na poziomie L1, mające wpływ na jakość wymowy L2, takie jak: niepłynność mówienia, defekty twa- 
rzowo-zgryzowe, anomalie zębowe, wady wymowy i inne, z czym wiąże się zainteresowanie zagadnieniem zastosowania metod logopedycznych w nauczaniu języka polskiego jako obcego (por. Świstowska 2011; Czempka-Wewióra, Graboń 2017). Kwestia ta pozostaje w bezpośrednim związku z istotnym w procesie nauki języka obcego odróżnieniem błędów wymowy od wad wymowy (Kamper-Warejko, Kaproń-Charzyńska 2015). Procedury postępowania w każdym przypadku nie powinny być takie same, a w sytuacjach wattpliwych lepiej zakwalifikować nieprawidłowości w wymowie jako wady i uwzględnić je, opracowując program terapii (por. Czempka-Wewióra, Graboń 2017).

\section{Badania własne}

Grupa studentów, których kompetencje fonetyczno-fonologiczne znalazły się w centrum mojego zainteresowania, przyjechała do Polski po ukończeniu w Chinach pierwszego roku polonistyki. W ramach zajęć z fonetyki podjęto działania mające na celu stwierdzenie, czy uwarunkowania biologiczne maja wpływ na ich realizacje fonetyczne. Ze względu na prezentowany przez studentów stopień znajomości języka polskiego (A1/A2) niemożliwe było przeprowadzenie pełnego badania logopedycznego ${ }^{2}$. Do tego dochodziła świadomość uczącej, że rozgraniczenie zaburzeń i problemów wynikających z utrwalonych wzorców języka pierwszego przy nieznajomości L1 studentów może okazać się trudne.

Kluczowe w tej sytuacji było ustalenie schematu postępowania. W ramach diagnozowania w logopedii wykorzystuje się dwa rodzaje technik badawczych - deskrypcję i interpretację. Deskrypcja obejmuje rejestrację i opis stanów oraz zachowań danej osoby, zaś interpretacja jest ich wyjaśnieniem (Grabias 2012, 61). Za D. Plutą-Wojciechowską (2015, 30) przyjęto, że wyróżniamy trzy typy trudności wymowy cudzoziemców: a) biologiczne, b) związane z wcześniej przyswojonym systemem fonetyczno-fonologicznym, c) związane ze sposobem uczenia L2. W związku z powyższym na etapie diagnostycznym w ramach deskrypcji należało ustalić a) biologiczne czynniki ryzyka oraz b) realizacje fonetyczne. Następnym krokiem było przejście do inter-

2 M. Czempka-Wewióra i K. Graboń (2017), które przedstawiły schemat postępowania logopedycznego na zajęciach nauki języka polskiego jako obcego, doszły do wniosku, że pełne badanie logopedyczne może być przeprowadzone od poziomu B1. 
pretacji, w ramach której orzeka się o rodzaju odstępstwa od normy. Musi ona uwzględniać zarówno czynniki biologiczne, jak i te związane z przyswojonym wcześniej systemem fonetyczno-fonologicznym. Ustalenie tych typów trudności ma zasadniczy wpływ na typ trzeci, wymieniony przez D. Plutę-Wojciechowską, czyli ten związany ze sposobem uczenia L2.

\section{Deskrypcja}

Uwage skoncentrowano na wybranych elementach postępowania logopedycznego, mieszczących się w zakresie diagnozy kompetencji fonetyczno-fonologicznych, takich jak: ocena stanu i sprawności aparatu artykulacyjnego, orientacyjne badanie słuchu, badanie słuchu fonemowego, ocena artykulacji głosek w izolacji oraz w kontekście w różnych pozycjach, płynność mowy. Elementy badano z wykorzystaniem dostępnych w literaturze logopedycznej wskazówek i ćwiczeń (por. Demel 1978; 1987; Styczek 1981; Minczakiewicz 1987; Jastrzębowska 1998; Sołtys-Chmielowicz 2008; Czaplewska 2015). Przygotowany na ich bazie materiał sprawdzajacy posłużył do oceny określonych kompetencji.

Płynność mowy, którą można było usłyszeć w czasie swobodnych rozmów ze studentami, nie była zaburzona. Próby języka, warg i ćwiczeń ruchomości żuchwy pozwoliły ocenić stan anatomiczny i sprawność aparatów artykulacyjnych. W omawianych obszarach nie stwierdzono nieprawidłowości. Studenci nie mieli problemów z precyzją i celowością wykonywanych ruchów, nie stwierdzono u nich wad zgryzu i anomalii zębowych, które mogłyby wpływać na zaburzenia artykulacji. Nie mieli także problemów ze wskazywaniem źródła dźwięku, różnicowaniem jego wysokości i natężenia. Kluczowe okazało się badanie słuchu fonemowego oraz ustalenie zasobu dźwięków.

Badanie słuchu fonemowego, oparte na próbie literowej, sylabowej i wyrazowej, ma na celu ocenę różnicowania głosek o zbliżonych cechach artykulacyjnych i akustycznych. Zaburzenia w tym zakresie mogą dotyczyć par głosek, które różnią się tylko jedną cechą dystynktywną lub co najmniej dwiema z nich (por. Czaplewska 2015, 79)33. Wymienione próby można

3 Oba rodzaje zaburzeń słuchu fonemowego (związane z jedną lub kilkoma cechami) E. Czaplewska $(2015,80)$ proponuje uznać za zaburzenia fonologiczne. 
przeprowadzić w grupie osób, którym znany jest polski alfabet, a ich poziom znajomości języka polskiego pozwala na odczytywanie i zapisywanie znaków. Studenci z Chin spełniali te warunki. Próba literowa polegała na zaznaczaniu znaków graficznych głosek wypowiadanych przez nauczyciela.

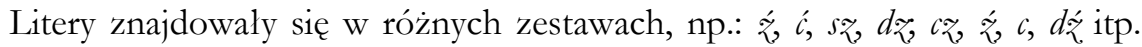
W próbie sylabowej badani, słuchając sylab wypowiadanych przez nauczyciela, sygnalizowali po kolei powtórzenie którejś z nich przez uniesienie ręki, np.: $p a, b a, p a, d a$. Próbę wyrazową przeprowadzono w oparciu o samodzielnie przygotowane na potrzeby praktyki logopedycznej obrazki paronimów. Nazwy różniły się głoskami ze względu na dźwięczność, miejsce artykulacji, stopień zbliżenia narządów mowy, np. [puukka] - [buukka], [buty] - [budy], [kura $]$ - [kula], [kasa $]-[$ kaša $]$, [fala $]-[$ sala $],[$ kot $]-[$ koc $]$, [domp] - [zomp] itp. W obrębie badania słuchu fonemowego mieściły się także próby analizy słuchowej wyrazów, obejmujące podanie liczby głosek i sylab w wyrazie oraz głoski (spółgłoski, półsamogłoski, samogłoski) słyszanej w nagłosie, wygłosie czy śródgłosie.

Przeprowadzone testy badania słuchu fonemowego w grupie dziesięciorga studentów z Chin pozwoliły stwierdzić następujące odstępstwa od normy w zakresie różnicowania dźwięków:

- spółgłoska bezdźwięczna - dźwięczna [c] - [3], [č] - [̌̌], [ć] - [3́], [f] [v];

- spółgłoska przedniojęzykowo-zębowa - przedniojęzykowo-dziąsłowa: $[\mathrm{c}]-[\mathrm{c}],[3]-[\check{3}]$;

- spółgłoska przedniojęzykowo-zębowa - środkowojęzykowa: [c] - [ć], [z] - [ź $],[3]-[3 ́$;

- spółgłoska twarda - zmiękczona: $[\mathrm{z}]-\left[\mathrm{z}^{\prime}\right],[\mathrm{s}]-\left[\mathrm{s}^{\prime}\right]$;

- spółgłoska szczelinowa - zwarto-szczelinowa: [z] - [3];

- spółgłoska półotwarta boczna [1] - spółgłoska półotwarta drżąca [r].

Większa liczba osób w badanej grupie nie różnicowała dźwięków ze względu na opozycję dźwięczności spółgłosek wargowo-zębowych [f] - [v] (7 osób), spółgłosek przedniojęzykowo-zębowych [c] - [3] (4 osoby) i przedniojęzykowo-dziąsłowych [č] - [ร̌] (3 osoby). Problem z różnicowaniem dźwięków przedniojęzykowo-zębowych - przedniojęzykowo-dziąsłowych wystapił w sumie u czterech badanych. W wypadku trzech z nich była to opozycja [3] - [క̌] (każda z tych osób nie różnicowała ponadto jednej pary głosek różniących się cechą dźwięczności, a także szeregów spółgłoska szczelinowa twarda - miękka lub twarda - zmiękczona), u jednego studenta była to opozycja [c] - [č] (osoba ta nie rozróżniała także opozycji dźwięczna 
[v] - bezdźwięczna [f]). Dźwięków [ć] - [3́] nie różnicowała jedna osoba. Opozycja spółgłoska przedniojęzykowo-zębowa i środkowojęzykowa stanowiła problem dla trzech studentów. Tylko jedna osoba nie rozróżniała opozycji spółgłoska twarda i zmiękczona [z] - [z’] i [s] - [s']. Także jedna, u której wystąpiły problemy z różnicowaniem opozycji pod względem dźwięczności (dotyczyły one par [f] - [v], [č $-[\check{3}]$ i [c] - [3]), nie słyszała różnicy między spółgłoską szczelinową [z] i zwarto-szczelinową [3]. Problemy z różnicowaniem dźwięków spoza trójszeregu (oprócz wymienionej wyżej opozycji dźwięczna - bezdźwięczna spółgłoska wargowo-zębowa) dotyczyły spółgłoski półotwartej bocznej [1] i spółgłoski półotwartej drżącej [r] w wypadku dwojga badanych.

Badania artykulacji dźwięków w izolacji i w kontekście pozwoliło zaobserwować:

a) zastępowanie spółgłoski [v] półsamogłoską [u];

b) zastępowanie środkowojęzykowych dźwięków [ź], [3́], [ć], [ś] spółgłoskami przedniojezykowymi retrofleksywnymi (przód języka jest wygięty ku górze, a jego czubek tworzy zaporę w okolicy zadziąsłowej);

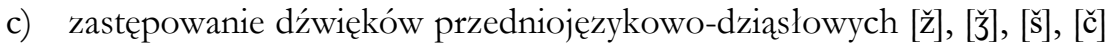
przedniojęzykowymi retrofleksywnymi;

d) zastępowanie spółgłoski przedniojęzykowo-dziąsłowej drżącej [r] spółgłoską [1] lub spółgłoską welarną.

Trzy osoby zamiast spółgłoski [v] realizowały półsamogłoskę [u]. Zastępowanie spółgłosek środkowojęzykowych spółgłoskami retrofleksywnymi zostało stwierdzone w sumie u siedmiu studentów. Cztery osoby wymawiały spółgłoski przedniojęzykowe retrofleksywne zamiast przedniojęzykowo-dziąsło-

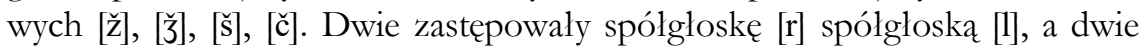
zamiast [r] wymawiały dźwięk, który jest identyfikowany w rotacyzmie podniebiennym, kiedy to tylna część języka zbliża się do podniebienia miękkiego. $\mathrm{Na}$ uwage zasługuje występowanie u jednej osoby, u której stwierdzono niesłyszenie różnicy między spółgłoską szczelinową i zwarto-szczelinową, zniekształceń związanych z artykulacją spółgłosek [s] i [3], wynikających z nieprawidłowego ułożenia języka podczas artykulacji tych dźwięków.

\section{Interpretacja}

Badania słuchu fonemowego i artykulacji doprowadziły do wniosku, że problem z różnicowaniem i/lub realizacją dźwięków spółgłoskowych ma 
w sumie ośmioro studentów. Trudności dotyczą przede wszystkim spółgłosek ciszących, syczących i szumiących. W grę wchodziło ich nieróżnicowanie ze względu na cechę dźwięczności i miejsce artykulacji - zostało ono stwierdzone u kilku osób. Często występowało także nieróżnicowanie pod względem dźwięczności głosek wargowo-zębowych [v] i [f], zastępowanie w wymowie spółgłoski [v] półsamogłoską [u] n nieróżnicowanie spółgłosek $[\mathrm{r}]-[1]$ oraz niemieszcząca się w normie ortofonicznej polszczyzny artykulacja [r]. Taki stan rzeczy pozwalał na postawienie hipotezy, że nieprawidłowości, które ujawniły się podczas badania słuchu fonemowego i artykulacji, nie maja charakteru biologicznego, lecz wynikaja $z$ interferencji. W celu jej potwierdzenia konieczne było przyjęcie jako punktu odniesienia systemu fonetyczno-fonologicznego L1 studentów.

Najważniejsze różnice między systemami fonetyczno-fonologicznymi języków polskiego i chińskiego oraz związane z nimi problemy dotyczące dźwięków syczących, szumiących i ciszących przedstawiają się następująco: M. Młynarczyk pisze (powołując się na prace Künstler 2000 i San 2007), że w języku chińskim nie ma opozycji dźwięczność - bezdźwięczność, która w polszczyźnie służy różnicowaniu znaczeń wyrazów, a więc jest cechą dystynktywna. Autorka podaje, że spółgłoski szczelinowe dźwięczne [z], [ž] i [ź] nie występują w chińskim, spółgłoski [̌̌s], [č] są retrofleksywne (por. Młynarczyk 2013, 136-137). W związku z powyższym badacze zajmujący się problematyką nauczania języka polskiego jako obcego wskazują, że Chińczykom sprawiaja problem głoski palatalne oraz szumiące [ž] i [ź], [š] i [śs, [č] i [ć] (por. Malejka 2007). Zmiękczają oni spółgłoski przedniojęzykowo-dziąsłowe (Malejka 2007; Młynarczyk 20134), nie słyszą różnicy między głoskami przedniojęzykowo-zębowymi szczelinowymi i zwarto-szczelinowymi, por.:

Aby więc osoba chińskojęzyczna usłyszała różnicę między polskimi wyrazami: cerować i zerować, koca i koza lub kosa, musimy najpierw wskazać sposób artykulacji tych głosek: wyraźne dotknięcie czubkiem języka zębów w następie (na samym początku) głoski [c] i brak takiego zetknięcia przy wymowie głoski [z] (Tambor 2010, 45).

Na podstawie przedstawionych danych można stwierdzić, że w badanej grupie studentów z Chin zastępowanie spółgłosek ciszących i szumią-

\footnotetext{
${ }^{4}$ M. Młynarczyk (2013) pisze o problemach artykulacyjnych, które wynikają z niewystępowania dźwięków w chińskim lub występowania w nim dźwięków zbliżonych do polskich, nie wypowiada się na temat ich różnicowania słuchowego.
} 
cych spółgłoskami przedniojęzykowo-dziąsłowymi retrofleksywnymi jest wynikiem interferencji i wiąże się z tym, że w języku chińskim, w wymowie spółgłosek określanych jako szumiące, miejsce zwarcia lub szczeliny jest przesunięte ku podniebieniu twardemu w stosunku do spółgłosek polskich. Jako wynik wpływu L1 można też tłumaczyć niesłyszenie przez studentów opozycji pod względem dźwięczności w parach [c] - [3], [č] [3̌], [ć] - [3́], a także niesłyszenie różnicy między spółgłoskami przedniojęzykowo-zębowymi i przedniojęzykowo-dziąsłowymi oraz przedniojęzykowo-zębowymi i środkowojęzykowymi. Z interferencji wynika także wskazane przez J. Tambor (2010) niesłyszenie różnicy między głoskami przedniojęzykowo-zębowymi szczelinowymi i zwarto-szczelinowymi, choć zwraca uwagę fakt, że zostało ono stwierdzone tylko u jednej z badanych osób.

Brak w języku chińskim opozycji dźwięczność - bezdźwięczność, a także niewystępowanie w nim spółgłoski szczelinowej dźwięcznej [v] (por. Młynarczyk 20135) i nieznajomość opozycji fonologicznej między [v] i [u]], na które zwraca uwage J. Malejka (2007), niewątpliwie ma wpływ na nieróżnicowanie słuchowe przez studentów głosek [f] i [v], jak i na zastępowanie ich w wymowie dźwiękiem [u] , które zostało stwierdzone u kilku badanych osób ${ }^{6}$. Na utrwalanie się tego zjawiska może mieć wpływ także znajomość języka angielskiego, w którym za literą $w$ kryje się dźwięk [ü].

J. Malejka (2007) oraz J. Tambor (2010) podaja, że Chińczycy nie słyszą różnicy między sonorną boczną [1] i drżącą [r], przy czym pierwsza z badaczek stwierdza, że studenci chińscy bez większych problemów artykułuja [r], a druga, że nie realizują różnicy między wskazanymi głoskami. M. Młynarczyk (2013) z kolei wymienia wśród trudności artykulacyjnych w grupie chińskich studentów bezdźwięczna, retrofleksywną artykulację [r]. Jak wynika z przeprowadzonych analiz, dwóch studentów zastępowało spółgłoskę półotwartą drżąca $[\mathrm{r}]$ spółgłoską półotwartą boczną [1]. Te same osoby nie różnicowały wymienionych dźwięków słuchowo. Dwoje badanych zamiast [r] wymawiało dźwięk, który jest identyfikowany w rotacyzmie podniebiennym, kiedy tylna część języka zbliża się do podniebienia miękkiego.

${ }^{5}$ J. Malejka (2007) wskazuje na brak opozycji dystynktywnej [v] i [f] w języku chińskim.

${ }_{6} \mathrm{Na}$ zastępowanie spółgłoski [v] dźwiękiem półsamogłoskowym tylnym zwraca uwage M. Młynarczyk (2013). 


\section{Zakończenie}

Dotarcie do źródeł zakłóceń dźwięków i błędów fonetycznych pozwala wejść w etap programowania procesu glottodydaktycznego. Świadomość, że ma się niewielką liczbę godzin do dyspozycji, przekonuje, jak istotny jest problem doboru metod pracy. W przypadku opisywanej grupy studentów z pierwszym językiem chińskim na zajęciach wykorzystano metody logopedyczne i lingwistyczne. Wśród metod szczegółowych znalazły się: ćwiczenia słuchu fonemowego i autokontroli słuchowej, ćwiczenia usprawniające narządy mowy, ćwiczenia artykulacyjne, pokazywanie ułożenia narządów mowy, kontrola wzrokowa, metoda substytucyjna (metoda Seemana), ćwiczenia dykcyjne ${ }^{7}$. Obejmowały one modalność wzrokową, słuchową i kinestetyczną. Ich przydatność do nauczania fonetyki jpjo nie ulega watpliwości. Ułatwiły one ustalenie charakteru występujących u słuchaczy odstępstw od normy oraz zaprojektowanie kompleksowych działań, mających na celu osiagnięcie poprawnych realizacji fonemów.

\section{Bibliografia}

Bielawska M., 2018, Jak wspomagać rozwój jezykowy dz̧ieci wielojezycznych? Postępowanie logopedyczne w nauczaniu jezykea polskiego jako obcego, „Logopaedica Lodziensia”, nr 2.

Biernacka M., 2015, Nauczanie fonetyki jezyka polskiego jako obcego w swietle technik nauczania wybieranych przez autorów wspótczesnych podręcznikón, w: Gaze M., Góralczyk-Mowczan P., red., Bogactwo jezykowe i kulturowe Europy w oczach Polakón i cudzoziemców, t. 3, Łódź.

Cieszyńska-Rożek J., 2015, Metody badania systemu jezykowego dzieci dwu- $i$ wielojezycznych, w: Milewski S., Kaczorowska-Bray K., red., Metodologia badań logopedycznych: z, perspek.tywy teorii i praktykki, Gdańsk.

Cieszyńska-Rożek J., 2018, Glottodydaktyka i logopedia (metoda krakonskea), https://szkolap olska.is/szkola/biezace-informacje/glottodydaktyka-i-logopedia-metoda-krakowska [dostęp: 17.02.2019].

Czaplewska E., 2015, Diagnoza z̧aburžeń rožwoju artykulacji, w: Czaplewska E., Milewski S., red., Diagnoza logopedyczna, Gdańsk.

Czempka-Wewióra M., Graboń K., 2017, Diagnoz̧a i postępowanie logopedycznne w nauczaniu jezykea polskiego jako obcego, „Postscriptum Polonistyczne”, nr 1 (19).

Demel G., 1978, Minimum logopedyczne nauczyciela przedsækola, Warszawa.

Demel G., 1987, Elementy logopedii, Warszawa.

\footnotetext{
${ }^{7} \mathrm{Na}$ ten temat por. Jastrzębowska (1998, 408-412).
} 
Grabias S., 2012, O ostrość refleksji naukowej. Prz̧edmiot logopedii i procedury logopedycznego postępowania, w: Milewski S., Kaczorowska-Bray K., red., Logopedia. Wybrane aspekty bistorii, teorii ipraktyki, Gdańsk.

Jastrzębowska G., 1998, Podstawy teorii i diagnozy logopedycznej, Opole.

Kania J.T., 2001, Szkice logopedyczne, Lublin.

Kamper-Warejko J., Kaproń-Charzyńska I., 2015, Bład wymowy cæy wada wymowy. Rozważania na marginesie nauki jezyków obcych, „Linguododactica”, t. XIX.

Kubicka E., 2010, Miejsce fonetyki w nauczaniu jezyka polskiego - teoria a praktyka, w: Taczyńska K., Birecka K., red., Nowe perspektywy w nauczaniu jezykea polskiego jako obcego, Toruń.

Künstler M.J., 2000, Jezyki chinskie, Warszawa.

Kyrc B., 2018, W poszukiwaniu narzedzia diagnostycznego - ocena kompetencji jezylkowej dzieci dwujezycznych na etapie wczesnoszkolnym, „Acta Universitatis Lodziensis. Kształcenie Polonistyczne Cudzoziemców", nr 25.

Madelska L., 2010, Między logopediq a glottodydaktyka, „Wielkopolski Przegląd Logopedyczny”, nr $1 / 9$.

Majewska-Tworek A., 2005, Trudności fonetyczne i fonologiczne niemieckojezycznych studentów uczacych sie jezykea polskiego jako obcego, w: Garncarek P., red., Nauczanie jezylka polskiego jako obcego i polskiej kultury w nowej rzeczymistości europejskiej, Warszawa.

Malejka J., 2007, Jak uçyć Chińczylków mymowy polskiej, w: Studia polonistyczne w Az̋ji, Department of Polish Studies East European and Balkan Institute Hankuk University of Foreign Studies, Korea; Embassy of the Republic of Poland in Korea, Seul.

Minczakiewicz E., 1987, Logopedia. Wybrane zagadnienia z. materiałami do íwiczeń, Kraków.

Młynarczyk M., 2013, Artykulacja polskich gtosek u chińskich studentów uczacych sie jezyka polskiego, „Acta Universitatis Wratislaviensis”, nr 3551, „Studia Linguistica”, nr XXXII.

Młyński R., 2012, Dwujezyczność driecięca w perspektywie glottodydaktyki i logopedii, w: Michalik M., Siudak A., Orłowska-Popek Z., red., „Nowa Logopedia”, t. 3, Diagnoza różnicowa zaburžeń komunikacji, Kraków.

Pilch T, Bauman T., 2010, Zasady badań pedagogicznych. Strategie ilościowe i jakościowe, Warszawa.

Pluta-Wojciechowska D., 2015, Wymowa cudzoziemcón uczacych sie jezyka polskiego jako L2 w oczach logopedy: rekonesans zagadnien, „Forum Logopedyczne”, nr 23.

San Duan-mu, 2007, The Phonology of Standard Chinese, Oxford \& New York.

Seretny A., Lipińska E., 2005, ABC metodyki nauczania jezykea polskiego jako obcego, Kraków.

Styczek I., 1981, Logopedia, Warszawa.

Sołtys-Chmielowicz A., 2008, Zaburzenia artykulacji. Teoria i praktyka, Kraków.

Szmidt D.T., Castellví J., 2011, Cechy charakterystyczne fonetyki polskiej w nauczaniu Katalończylków, w: Nycz R., Miodunka W., Kunz T., red., Polonistyka bez granic, t. 2, Kraków.

Świstowska M., 2011, Międry logopedia a glottodydaktyka. Zastosowanie metod logopedycznych w nauczaniu polskiego jako obcego, w: Nycz R., Miodunka W., Kunz T., red., Polonistyka bez granic, t. 2, Glottodydaktyka polonistycz̨na - wspótczesny jezylk polski - jezykony obraz świata, Kraków.

Tambor J., 2010, Nauczanie wymowy polskiej. Trudności różnych grup cudzoziemców, w: Achtelik A., Kita M., Tambor J., red., Sztuka i rzemiosto. Nauczyć Polski i polskiego, t. 2., Katowice.

Tambor J., 2012, Poprawna wymowa polska. Przewodnik dla cudzoziemców i ich nauczycieli, w: Maciołek M., Tambor J., Gtoski polskie. Przewodnik fonetyczny dla cudzoziemców i nauczycieli uczacych jezyke polskiego jako obcego, Katowice.

Węsierska K., 2014, Interwencja logopedycそna w praypadku jakania u osób bilingwalnych, w: Kuros- 
-Kowalska K., Loewe I., red., Dwujezyczność, wielojezycznośc i wielokulturowość. Szanse i zagrożenia na drodze do porozumienia, Gliwice.

Wiśniewski M., 1998, Zarys fonetyki i fonologii wspótczesnego jezylka polskiego, Toruń.

Woźniewicz W., 1987, Kierowanie procesem glottodydaktycznym, Warszawa.

Wójtowicz J., 1980, Wymowa polska a nauczanie cudzoziemców, w: Lewandowski J., red., Metodyka nauczania jezylka polskiego jako obcego, Warszawa.

Iwona Kaproń-Charzyńska - dr hab., prof. UMK, Instytut Językoznawstwa, Katedra Języka Polskiego, Uniwersytet Mikołaja Kopernika w Toruniu, Toruń, Polska.

Językoznawca, absolwentka studiów podyplomowych w zakresie logopedii. Jej zainteresowania badawcze obejmują leksykę współczesnej polszczyzny, morfologię, pragmatykę, problemy teoretyczne językoznawstwa oraz rozwój mowy dziecka. Jest autorką trzech monografii: Derywacja ujemna we współczesnym języku polskim. Rzeczowniki i przymiotniki (Toruń 2005), Pragmatyczne aspekty słowotwórstwa. Funkcja ekspresywna i poetycka (Toruń 2014) i Kształtowanie się systemu językowego w zakresie kategorii przypadka rzeczowników u dzieci 5- i 6-letnich (Toruń 2016, wspólnie z Joanną Kamper-Warejko).

Kontakt: ikap@umk.pl 